\title{
IV KONGRES MARIOLOGICZNY I MARYJNY W OLSZTYNIE I GIETRZWALDZIE
}

W dniach od 24 do 26 czerwca 1977 r. odbył się w Olsztynie i Gietrzwałdzie na Warmii IV Ogólnopolski Kongres Mariologiczny i Maryjny, zorganizowany przez Ks. Bpa J. Drzazgę Ordynariusza diec. Warmińskiej, oraz O. B. Przybylskiego OP.

W pierwszych dwóch dniach obrady toczyły się w Olsztynie i miały charakter ściśle naukowy. Problematyka obrad związana była ze stuletnią rocznicą objawień się Matki Bożej w Gietrzwaldzie (od 27 czerwca do 9 września 1877 r.). W związku z tym wygłoszono 4 centralne referaty i 9 komunikatów, których zadaniem było naukowe określenie historyczności tych objawień, ich autentyczności, oraz teologicznego znaczenia.

Ks. Bp J. Obłak w swoim referacie wprowadzającym nt. „Objawienia Matki Bożej w Gietrzwałdzie w świetle archiwaliów diecezjalnych, ze szczególnym uwzględnieniem treści posłania", przedstawił historię tych objawień, omówił szczegółowo ich autentyczność oraz ustosunkował się krytycznie do pewnych osób, które uważały, że także miały objawienia. Ks. Bp stanął na stanowisku, że za autentyczne można uznać tylko objawienia, jakie miały Barbara Samulowska i Justyna Szafryńska. W czasie tych objawień, Matka Najśw. nawoływała do trzeźwości, pokuty i odmawiania różańca. Objawienia te miały także i pewien wydźwięk narodowy, ponieważ Matka Boża przemawiała do dziewcząt po polsku.

Drugi refert Ks. doc. M. Borzyszkowskiego, nt. „Historia objawien w Gietrzwałdzie w świetle źródeł archiwalnych zachodnioniemieckich", omawiał reakcję na objawienia się w Gietrzwałdzie poza granicami Polski, a szczególnie akcentował postawę ówczesnych władz kościelnych do tychże objawień. Zdaniem referenta, władze kościelne zachowały wielką ostrożność, ale odnośnie samych objawień nie dały oficjalnego oświadczenia.

Następni referenci, Ks. prof. Wł. Piwowarski z Lublina i Ks. prof. T. Pawluk z Warszawy, zajmowali się zagadnieniem reakcji wiernych na powyższe abjawienia. I tak pierwszy referent omówił ,Eosiery” (tj. pielgrzymki) do Gietrzwałdu", które stanowiły zewnętrzny dowód wiary i uznawania przez wiernych powyższych objawień, zaś drugi referent naświetlił stanowisko Kościoła w odniesieniu do prywatnych objawień. W referacie swoim na temat: "Stosunek Kościoła do objawień prywatnych", oświadczył, że Kościół przyjmuje możliwość prywatnych objawień, choć te objawienia nie wnoszą nic do depozytu objawienia Bożego, a tylko kierują naszym postępowanem. Dlatego też Kościół nie nakłada na wiernych ścisłego obowiązku wierzenia w te obljawienia.

Niejako uzupełnieniem do powyższych referatów, były komunikaty, w których poszczególni referenci poruszali już bardzo szczegółową, ale niemniej ciekawą problematykę. Tytuły poszczególnych komunikatów sa następujące: Ks. Br. Tomczyk CM, "Siostra Miłosierdzia Stanisława (Barbara) Samulowska, (†1950), wizjonerka z Gietrzwałdu", Ks. Zb. Jakubowski CRL, „Ks. Augustyn Wiechsel, proboszcz gietrzwałdzki w czasie objawień", Ks. H. Madej, „Sanktuaria Maryjne na Warmii”, J. Piskorska, „Rozwój sanktuarium gietrzwałdzkiego”, Ks. Wł. Nowak, „Historia obrazu i kultu Matki Bożej Gietrzwałdzkiej”, O.G. Bartoszewski OFMCap, „Niedrukowany rękopis sługi Bożego O. Honorata Koźmińskiego o objawieniach w Gietrzwałdzie", Ks. J. Kowallewski, „Echa objawień gietrzwałdzkich w ,Gazecie Olsztyńskiej”, Ks. E. Piszcz, „Echa objawień gietrzwałdzkich w „Pielgrzymie”, M. Wójcik, ,Objawienie Matki Bożej Gietrzwałdzkiej a Zgromadzenie S. Służek Najśw. Maryi Panny Niepokalanej z Mariówiki". 
O wielkim zainteresowaniu się problematyką Kongresu świadczyła żywa dyskusja, w której dążono nie tylko do sprecyzowania pewnych jeszcze niejasnych momentów samych objawień, ale przede wszystkim do wyciąnnięcia praktycznych wniosków, dotyczących autentycznego kultu maryjnego w codziennym naszym życiu chrześcijańskim.

W Kongresie wzięli udział przedstawiciele niemal wszystkich ośrodków naukowych z całej Polski, jak również przybyli nań licznie przedstawiciele duchowieństwa diecezjalnego i zakonnego oraz liczne siostry zakonne. Obradom Kongresu przewodniczył Ks. Kard. K. Wojtyła oraz Bp Kraszewski, przy współudziale O. Pawła Melady z Rzymu, prezesa Międzynarodowej Akademii Maryjnej, O. B. Przybylskiego OP, Ks. Bpa St. Bareły. Nad całością obrad czuwał Ks. J. Drzazga, miejscowy Ordynariusz, oraz jego biskupi pomocniczy: Bp J. Obłak i Bp J. Wojtkowski.

Niejako podsumowaniem obrad Kongresu mariologicznego był Kongres Maryjny, który miał miejsce w samym już Gietrzwałdzie w dniu 26 czerwea br. Głównym jego punktem była uroczysta msza św., celebrowana przez St. Barełę, oraz wygłoszone przez niego okolicznościowe kazanie. W kazaniu swoim celebrans zwrócił uwagę na obecność Matki Bożej w naszym narodzie, a szczególnie na jej obecność na Warmii, co miało wielkie znaczenie nie tylko dla religijności ale także i dla polskości tamtejszego ludu.

W czasie obu Kongresów odczytano listy od Ojca Swiętego Pawła VI oraz pod nieobecnego Ks. Prymasa Kard. Wyszyńskiego. Na zakończenie uroczystości w Gietrzwałdzie odbyła się uroczysta procesja różańcowa do cudownego źródełka」

Nie ulega wątpliwości, że Kongres Olsztyńsko-Gietrzwałdzki wniósł wiele nowych elementów do studiów nad maryjną problematyką, oraz przyczynił się do lepszego i właściwszego jej oceniania.

Kraków

Ks. Stanistaw Grzybek

\section{Ks. Jan Kowalski}

\section{DZIALALNOŚĆ POLSKIEGO TOWARZYSTWA TEOLOGICZNEGO W KRAKOWIE W ROKU 1976}

W roku 1976 Polskim Towarzystwem Teologicznym w Krakowie kierował Zarzad w składzie: Ks. Prof. dr habil. Bolesław Przy b y s ze w ski (prezes), Ks. dr Kazimierz Drzymała SJ (wiceprezes), Ks. lic. Antoni Okrzesik (sekretarz), Ks. lic. Mieczysław Pila t SDB (skarbnik) i Ks. dr habil. Antoni B a cińs ki CM (bibliotekarz). Skład Komisji Rewizyjnej był następujacy: przewodniczacy Ks. dr Stanisław Dabrow ski i członkowie: Ks. Prof. dr Franciszek M a charski oraz Ks. Prof. dr Jan Kowalski. Praca Towarzystwa koncentrowała się przede wszystkim na akcji odczytowej prowadzonej na comiesięcznych zebraniach zwyczajnych i w poszczególnych sekcjach, oraz na działalności wydawniczej.

Zarząd PTT, przy szczególnych zabiegach swego prezesa, powołał do życia, zgodnie ze Statutem, nową sekcję misjologiczną. Ponadto był on współorganizatorem Kongresu Teologów Polskich, który odbył się we wrześniu 1976 r. w Krakowie-Nowej Hucie (klasztor Ojców Cystersów). 